\title{
ГОТОВНОСТЬ К СЕМЕЙНОЙ ЖИЗНИ СТУДЕНТОВ, ОСТАВШИХСЯ БЕЗ ПОПЕЧЕНИЯ РОДИТЕЛЕЙ: ОПЫТ ЭМПИРИЧЕСКОГО ИССЛЕДОВАНИЯ
}

\author{
И. В. Федосова, А. В. Кибальник
}

Иркутский государственный университет, Иркутск

Рассматривается социально-психологический феномен «готовность к семейной жизни». Подчеркивается ведущая роль семьи в подготовке юношей и девушек к будущей семейной жизни и формировании у них осознанного отношения к созданию собственной семьи. Особое внимание обращено на студентов, оставшихся без попечения родителей и получивших опыт воспитания в интернатных учреждениях. Акцентируется внимание на факторах, которые способствуют искаженному восприятию семьи, неправильному усвоению социальных ролей данной категорией обучающихся. Представлены эмпирические данные изучения сформированности социально-психологического феномена готовности к семейной жизни у студентов вуза, оставшихся без попечения родителей, по следующим критериям: когнитивный, ценностно-мотивационный, эмоциональный, операционально-деятельностный. На основе материалов диагностики утверждается необходимость формирования готовности к семейной жизни у данной категории обучающихся на основе специально разработанной программы, которая направлена на формирование ценности семьи; расширение знаний о семье, закономерностях ее развития, семейном этикете, психологии пола; пропаганду положительного опыта жизнедеятельности семьи и семейного воспитания; взаимодействие субъектов образовательного процесса по воспитанию семейных духовно-нравственных ценностей и ответственного родительства.

Ключевые слова: семья, готовность к семейной жизни, студенты, обучающиеся, оставшиеся без попечения родителей, программа.

Усиление внимания к исследованию воспитательной функции семьи прослеживается в ряде научных областей: социологии, педагогике, психологии. Значимость семьи как института социализации неоспорима, именно в семье ребенок проводит большую часть времени, кроме того, воспитательное воздействие, оказанное на человека в семье, определяет его взгляды, жизненные установки, влияет на личностные предпочтения и идеалы.

Отличия в образовательном и общекультурном уровне, накопленном опыте, способностях к организации деятельности ребенка, специфика детско-родительских и супружеских отношений - все это обусловливает атмосферу в семье. Безусловно, семья - особый коллектив, оказывающий влияние на каждого члена, особенно велико это влияние на детей: в семье ребенок усваивает культуру родственных отношений, учится устанавливать эмоциональные связи и решать возникающие трудности. Однако не все семьи имеют достаточный воспитательный потенциал для обеспечения всех необходимых функций.

В последние годы наблюдается тенденция роста социального сиротства - увеличивается количество детей, чьи родители лишены родительских прав. На сегодняшний день в центрах помощи детям, детских домах проживает большое количество детей-сирот и детей, оставшихся без попечения родителей.

По мнению ряда авторов, причин социального сиротства несколько. Одна из основных - разрушение института семьи, как правило, из-за финансового неблагополучия и 
трудностей в жилищно-коммунальной сфере. Не выдержав сложностей, многие родители подвергаются алкогольной и наркотической зависимости [1-3]. Настает время, когда дети остаются никому ненужными, кроме государства. Интернатные учреждения для детей-сирот и детей, оставшихся без попечения родителей, - нравственно-педагогическая государственная система, призванная защищать несовершеннолетних граждан, создавать условия, схожие с домашними. Однако, несмотря на все усилия, ребенок остается лишенным семейной любви и заботы, связи с родственниками, что негативно сказывается на его личностном становлении.

Дети, которые с рождения воспитывались в интернатных учреждениях, в своем представлении не имеют модели гармоничной семьи и правильного родительского поведения. Это объясняется тем, что в таких учреждениях отсутствует подготовка подрастающего поколения к семейной жизни [4].

Детский дом является для детей-сирот и детей, оставшихся без попечения родителей, основной моделью социального мира, и от того, как будет построен процесс воспитания, зависит приобретение социального опыта детьми, основ человеческих взаимоотношений, умений и навыков обеспечения личной жизни и деятельности $[5,6]$.

С позиции социально-психологического решения данной проблемы очевидна необходимость специальной подготовки девушек и юношей, оставшихся без попечения родителей и сирот, к браку и семейной жизни. Это объясняется отсутствием у большей части таких ребят позитивного жизненного опыта в семье, первоначальных представлений о правах и обязанностях членов семьи, знаний содержания и характера внутрисемейных отношений, а также жизненно необходимых социально-бытовых навыков [7].

Существенный вклад в разработку проблемы подготовки детей-сирот и детей, оставшихся без попечения родителей, к будущей семейной жизни внесли современные отечественные исследователи: И. В. Дубровина, В. И. Жукова, Ж. А. Захарова, Н. А. Зимина, В. Н. Ослон, А. М. Прихожан и др. [8-14]. Однако в психолого-педагогической литературе отмечается относительная скудность теоретических и практических разработок, связанных с формированием готовности к семейной жизни обучающихся, оставшихся без попечения родителей. Целенаправленная подготовка юношей и девушек к семейной жизни в стенах социального учреждения для детей-сирот и детей, оставшихся без попечения родителей, и образовательной организации либо не ведется вообще, либо носит эпизодический, бессистемный характер.

Формирование готовности к семейной жизни является одним из основных направлений социального воспитания детей-сирот, так как готовность к семейной жизни - важный показатель социальной зрелости и психического здоровья личности, составляющий основу ее успешной самореализации и социальной интеграции.

Данное направление включает повышение социального статуса отцовства и материнства среди молодежи, осознание молодыми людьми ответственности перед семейной жизнью, формирование психологической готовности юношей и девушек к браку, освоение ими необходимых гигиенических сведений и знаний по уходу за детьми, основ психологии дошкольного периода детского развития, возрастной психологии, профилактику разного рода зависимостей и рассмотрение основ домоводства, а также умения и навыки рационального ведения бюджета семьи $[15,16]$.

Сохраняется необходимость актуализации представлений молодых людей о многообразии и содержании социальных ролей. Чаще всего у детей-сирот и детей, оставшихся без попечения родителей, эти представления искажены в силу отсутствия конструктивного родительского примера и противоречивости поступающей информации (мнения сверстников, 
примеры из средств массовой информации и пр.). Поэтому нередко образуется вымышленная социальная роль, причем она может касаться и других людей, не входящих в круг семьи. Таким образом, складывается иллюзорный образ своей роли как сироты [17].

Сензитивным периодом формирования готовности к семейной жизни является юношеский возраст, отличительными чертами которого выступают стремление к самостоятельности, потребность в самоопределении, приобретение психической, идейной и гражданской зрелости [18]. В юности происходит расширение временного горизонта - будущее становится для молодых людей главным, личность устремляется в ожидаемые события и определяется жизненный путь и выбор профессии. Юноши и девушки определяют для себя нравственные принципы, которые способствуют им в нахождении своего места в жизни. Так, проведенный обзор научных работ в данном направлении показал, что в ранней юности наиболее остро встают вопросы, касающиеся смысла жизненных проблем, формирования семейных установок, встречающихся у всех юношей и девушек без исключения.

В этот период складываются условия «риска», которые осложняют процесс формирования у молодежи готовности к семейной жизни. Затруднения материального плана, потребность и не всегда возможность личностного и профессионального самоопределения, доминанта в численности юношей и девушек по гендерному признаку во многих областях России приводят к психологическим проблемам у студентов на этапе поиска, выбора брачного партнера и создания семьи [19].

С целью проверки обозначенных нами теоретических выводов было проведено эмпирическое исследование уровня готовности студентов, оставшихся без попечения родителей, к семейной жизни. Экспериментальной базой стал Педагогический институт ФГБОУ ВО «Иркутский государственный университет». Исследовательская работа проводилась со студентами первого курса в возрасте 18-23 лет (25 обучающихся по разным направлениям и профилям подготовки). На этапе констатации данных (октябрь 2019 г.) выявлялся уровень сформированности когнитивного, ценностно-мотивационного, эмоционального и операционально-деятельностного критериев (табл. 1).

Для достижения поставленной цели мы использовали следующие методы исследования: изучение социально-педагогической документации, анкетирование, опрос, эссе, тестирование, метод сбора независимых характеристик.

Вначале мы проанализировали социально-педагогическую документацию обучающихся, относящихся к категории детей-сирот и детей, оставшихся без попечения родителей, изучили личные дела студентов, социальные паспорта учебных групп.

Большинство представителей молодежи данной категории имеют социальный статус «оставшиеся без попечения родителей» в связи с лишением взрослых родительских прав, признанием родителей безвестно отсутствующими, недееспособными, объявлением их умершими, отбыванием родителями наказания в учреждениях, исполняющих наказание в виде лишения свободы, нахождением в местах содержания под стражей, подозреваемых и обвиняемых в совершении преступлений, уклонением родителей от воспитания своих детей или от защиты их прав и интересов, отказом родителей взять своих детей из образовательных или медицинских организаций.

Кураторами учебных групп совместно с социальным педагогом и психологами оперативно осуществляется помощь данным студентам в решении учебных, социально-бытовых и других проблем. Всем обучающимся предоставляется общежитие. У детей-сирот и детей, оставшихся без попечения родителей, и лиц из их числа отмечается низкая и средняя успеваемость. 
Критерии, показатели и методы исследования уровня готовности к семейной жизни у обучающихся, оставшихся без попечения родителей

\begin{tabular}{|c|c|c|}
\hline $\begin{array}{c}\text { Критерии и уровни } \\
\text { готовности обучающихся } \\
\text { к семейной жизни } \\
\end{array}$ & $\begin{array}{c}\text { Показатели готовности } \\
\text { к семейной жизни }\end{array}$ & $\begin{array}{c}\text { Методы исследования } \\
\text { и диагностический } \\
\text { инструментарий } \\
\end{array}$ \\
\hline Когнитивный & $\begin{array}{l}\text { Теоретические знания о семье, ее } \\
\text { функциях, о взаимоотношениях в семье, } \\
\text { семейных ролях, о домашнем труде, } \\
\text { хозяйстве, бюджете, семье, досуге, } \\
\text { образовании, здоровье }\end{array}$ & $\begin{array}{l}\text { Метод эссе. Эссе } \\
\text { «Моя будущая семья» }\end{array}$ \\
\hline $\begin{array}{l}\text { Ценностно- } \\
\text { мотивационный }\end{array}$ & $\begin{array}{l}\text { Ценностные ориентации на семейную } \\
\text { жизнь; осознание семьи как ценности; } \\
\text { наличие мотивации на создание собст- } \\
\text { венной семьи, воспитание своих детей }\end{array}$ & $\begin{array}{l}\text { Тестирование. Методика } \\
\text { «Ценностные ориентации» } \\
\text { (М. Рокич). } \\
\text { Опрос. Опросник } \\
\text { «Семейные ценности» } \\
\text { (М. В. Мартынова, } \\
\text { М. С. Константинова) }\end{array}$ \\
\hline Эмоциональный & $\begin{array}{l}\text { Эмоционально-позитивные } \\
\text { представления о семейной } \\
\text { жизни, собственной роли в ней, } \\
\text { будущем супруге, детях, } \\
\text { родственниках }\end{array}$ & $\begin{array}{l}\text { Анкетирование. Анкета } \\
\text { «Семья» }\end{array}$ \\
\hline $\begin{array}{l}\text { Операционально- } \\
\text { деятельностный }\end{array}$ & $\begin{array}{l}\text { Практические навыки ведения } \\
\text { домашнего хозяйства, по заботе } \\
\text { и уходу за недееспособными } \\
\text { членами семьи }\end{array}$ & $\begin{array}{l}\text { Метод сбора независимых } \\
\text { характеристик }\end{array}$ \\
\hline
\end{tabular}

Для изучения первого критерия готовности к семейной жизни у обучающихся, оставшихся без попечения родителей, мы использовали метод эссе на тему «Моя будущая семья». Цель эссе заключалась в выявлении теоретических знаний студентов о семье, ее функциях, взаимоотношениях в семье, семейных ролях.

Нами было выяснено, что обучающиеся, оставшиеся без попечения родителей, представляют свою будущую семью «как очень дружный, веселый коллектив»; «добрую, веселую, честную, с двумя детьми, мальчик и девочка» и др. Некоторые уже придумали имена детям; «глава семьи будет мужчина, который будет добрым, ответственным». Также обучающиеся описывают деятельность будущего мужа или жены: «чтобы он обязательно работал и зарабатывал большие деньги, образование обязательно высшее было» (Анастасия К.). «мама должна быть хозяйкой, быть опорой своему мужу, должна обладать положительными качествами» (Мария Г.).

В некоторых сочинениях, например, обучающиеся писали следующее: «Семья: это жизнь, любовь, честность!» (Александр А.); «Семья, на мой взгляд, это мама и папа» (Алена С.); «Моя будущая семья будет состоять из 5 детей» (Елена М.).

Таким образом, в основном студенты представляют свою будущую семью адекватно, правильно понимают сущность понятия «семья», выполнение семейных ролей, обязанностей мужа и жены, понимают собственную роль в семье, значимость будущего избранника, детей.

Для изучения ценностно-мотивационного критерия готовности к семейной жизни обучающимся, оставшимся без попечения родителей, была предложена методика «Ценностные ориентации» М. Рокича и проведен опрос «Семейные ценности» М. В. Мартыновой, М. С. Константиновой.

Кратко дадим характеристику методам и методикам исследования. 
1. Методика «Ценностные ориентации» использовалась для ранжирования ведущих ценностей студентов и определения места ценности «Счастливая семейная жизнь» в их личной жизни.

Обработка результатов ранжирования ценностей производилась по двум спискам ценностей (по 18 в каждом). Каждой ценности присваивался ранговый номер. Мы взяли за основу только шесть первых ценностных категорий, представленных студентами. Вначале предъявлялся набор терминальных, а затем набор инструментальных ценностей. Данная методика помогла выявить нам установку ценностных ориентаций обучающихся на семейную жизнь; осознание семьи как ценности. Результаты представлены в табл. 2.

Таблица 2

Наиболее значимые иченности обучающихся, оставщихся без попечения родителей, по результатам диагностики по методике М. Рокича

\begin{tabular}{|c|l|l|}
\hline $\begin{array}{c}\text { Позиция } \\
\text { ценностей }\end{array}$ & \multicolumn{1}{|c|}{ Набор терминальных ценностей } & \multicolumn{1}{|c|}{ Набор инструментальных ценностей } \\
\hline 1 & $\begin{array}{l}\text { Материально обеспеченная жизнь } \\
\text { (отсутствие материальных затруднений) }\end{array}$ & $\begin{array}{l}\text { Воспитанность (хорошие манеры, } \\
\text { вежливость) }\end{array}$ \\
\hline 2 & Здоровье (физическое и психическое) & $\begin{array}{l}\text { Аккуратность (чистоплотность, умение } \\
\text { содержать в порядке свои вещи, } \\
\text { порядок в делах) }\end{array}$ \\
\hline 3 & Самостоятельность & $\begin{array}{l}\text { Терпимость к взлядам и мнениям } \\
\text { других (умение прощать другим их } \\
\text { ошибки и заблуждения) }\end{array}$ \\
\hline 4 & Красота природы и искусства & Жизнерадостность \\
\hline 5 & Счастливая семейная жизнь & Смелость \\
\hline 6 & Свобода (независимость) & Честность (правдивость, искренность) \\
\hline
\end{tabular}

По набору терминальных ценностей на первое место студенты ставят «материально обеспеченную жизнь (отсутствие материальных затруднений)», а «счастливая семейная жизнь» для них находится на предпоследнем месте (5-м). Что касается инструментальных ценностей, то на первом месте «воспитанность», на последнем - «честность (правдивость, искренность)». Исходя из результатов ранжирования, можно сделать вывод, что интересующая нас ценность «счастливая семейная жизнь» не представляется для большинства обучающихся, оставшихся без попечения родителей, главной в жизни, и многие студенты не выделяли эту ценность в числе первых, т. е. у них еще не сделан выбор, нет интереса в перспективе к созданию семьи и счастливой семейной жизни.

2. Опрос «Семейные ценности» М. В. Мартыновой, М. С. Константиновой. Цель опроса заключалась в определении представления студентов о взаимопонимании между членами семьи, почитании родителей, продолжении рода, заботе о младших и старших. В ходе проведения опроса нами были выявлены уровни сформированности ценностных представлений студентов о той или иной ценности по всем показателям. Обратимся к полученным данным проведенного опроса (рис. 1).

На основании полученных данных по опросу «Семейные ценности» мы распределили обучающихся по уровням сформированности ценностных представлений о семье: высокий, средний, низкий. Детей-сирот с высоким уровнем сформированности ценностных представлений о семье выявлено не было. Результаты, представленные на рис. 1, показывают, что 28 \% студентов (7 чел.) со средним уровнем сформированности ценностных представлений о семье не считают приоритетными для себя такие ценности, как любовь, продолжение рода, почитание родителей, забота о младших и старших, культура быта. 
Уровни сфрормированности ценностных представлений о семье

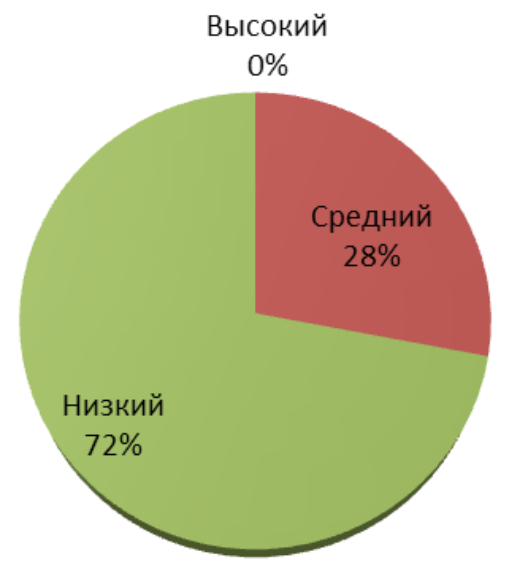

Рис. 1. Обобщенные результаты опроса «Семейные ценности»

Низкий уровень сформированности ценностных представлений о семье отмечен у 72 \% (18 чел.) обучающихся вуза, оставшихся без попечения родителей: у студентов не сформированы ценностные ориентации на создание семейной жизни. Связано это с тем, что у большинства из них отсутствует опыт жизни в гармоничной семье, нет элементарных представлений о правах и обязанностях членов семьи, особенностях позитивных внутрисемейных отношений, а также необходимых бытовых и социальных навыков.

Для изучения эмоционального критерия готовности к семейной жизни у обучающихся, оставшихся без попечения родителей, мы использовали метод анкетирования по методике «Семья». Анкета состояла из 12 закрытых вопросов. Интерпретация результатов осуществлялась, исходя из того, какие позиции выбирались обучающимися (табл. 3).

Таблица 3

Результаты анкетирования обучающихся по методике «Семья»

\begin{tabular}{|c|c|c|}
\hline $\begin{array}{l}\text { № } \\
\text { П/П }\end{array}$ & Вопросы и предложенные ответы & Количество ответов \\
\hline 1 & Пол & Ж $-22 ; \mathrm{M}-3$ \\
\hline \multirow{4}{*}{2} & \multicolumn{2}{|c|}{ Предпочитаемый возраст для вступления в брак, по мнению студентов } \\
\hline & 1) 26-30 лет & $67 \%$ \\
\hline & 2) 24-25 лет & $15 \%$ \\
\hline & 3) 21-23 года & $18 \%$ \\
\hline \multirow{4}{*}{3} & \multicolumn{2}{|c|}{ Возраст брачного партнера } \\
\hline & 1) 18-20 лет & $38 \%$ \\
\hline & 2) 21-23 года & $46 \%$ \\
\hline & 3) $24-25$ лет & $16 \%$ \\
\hline \multirow{3}{*}{4} & \multicolumn{2}{|c|}{ В семье должно быть } \\
\hline & 1) 2 ребенка & $77 \%$ \\
\hline & 2) 1 ребенок & $23 \%$ \\
\hline \multirow[b]{2}{*}{5} & \multicolumn{2}{|c|}{ Доход семьи, который смог бы обеспечить нормальньй уровень проживания } \\
\hline & 25000 рублей минимум & $100 \%$ \\
\hline \multirow{3}{*}{6} & \multicolumn{2}{|c|}{ Настроеньл активно заниматься домашним хозяйством } \\
\hline & 1) да, при этом в равной степени муж и жена & $69 \%$ \\
\hline & 2) да & $31 \%$ \\
\hline \multirow[b]{2}{*}{7} & \multicolumn{2}{|c|}{ Предпочтение жить } \\
\hline & $\begin{array}{l}\text { 1) город } \\
\text { 2) село }\end{array}$ & $\begin{array}{c}100 \% \\
0 \%\end{array}$ \\
\hline \multirow{3}{*}{8} & \multicolumn{2}{|c|}{ Инициатором разрешения конфликтов в семье должен(на) стать } \\
\hline & 1) муж & $73 \%$ \\
\hline & 2) жена & $27 \%$ \\
\hline
\end{tabular}


Федосова И. В., Кибальник А. В. Готовность к семейной жизни студентов...

\begin{tabular}{|c|c|c|}
\hline $\begin{array}{c}\text { № } \\
\Pi / \Pi \\
\end{array}$ & Вопросы и предложенные ответы & Количество ответов \\
\hline \multirow{4}{*}{9} & \multicolumn{2}{|c|}{ Главой семьи должен(ьы/на) быть } \\
\hline & 1) сразу оба & $23 \%$ \\
\hline & 2) жена & $42 \%$ \\
\hline & 3) муж & $35 \%$ \\
\hline 10 & Не готовы к браку все испытуемые & $100 \%$ \\
\hline 11 & Быть хорошим мужем - это значит: & $\begin{array}{l}\text { «любить жену, понимать и считаться с } \\
\text { ее мнением, любить детей, заниматься } \\
\text { воспитанием их, заботиться о семье, не } \\
\text { курить, не пить, зарабатывать много } \\
\text { денег» }\end{array}$ \\
\hline 12 & Быть хорошей женой - это значит: & $\begin{array}{l}\text { «любить мужа, быть доброй, ласковой, } \\
\text { нежной, понимать и уважать интересы } \\
\text { мужа, с удовольствием вести домашнее } \\
\text { хозяйство, уметь вкусно готовить, быть } \\
\text { аккуратной, не капризничать, не быть } \\
\text { слишком требовательной» }\end{array}$ \\
\hline
\end{tabular}

Примечание. Ж - женский пол; М - мужской пол.

Испытуемые считают, что предпочитаемый возраст для вступления в брак должен быть от 26 до 30 лет (67 \%). Студенты убеждены, что главой семьи должна быть женщина (42 \%). Не исключают возможность патриархальной семьи 35 \% студентов, лишь 23 \% считают, что это должны быть оба члена семьи.

На вопрос, сколько в семье должно быть детей, анкетируемые дают следующие ответы: 2 ребенка (77 \%), т. е. бо́льшая часть испытуемых, остальная часть опрашиваемых думает, что достаточно одного (23 \%). Настроены активно заниматься домашним хозяйством $31 \%$ студентов, 69 \% ответили «да», при этом в равной степени муж и жена. Инициатором разрешения конфликтов в семье по мнению 73 \% опрошенных должен стать муж, $27 \%$ - жена. Таким образом, неготовность к браку наблюдается у всех испытуемых - 25 человек (100 \%).

Для изучения следующего критерия готовности к семейной жизни (операциональнодеятельностного) был использован метод сбора независимых характеристик. Были опрошены социальный педагог, кураторы студенческих групп и воспитатели общежития. Они давали характеристику сформированности практических навыков студентов, проживающих в общежитии.

Метод сбора независимых характеристик позволил выделить две группы обучающихся, оставшихся без попечения родителей, у которых:

1) развиты навыки эффективного общения и взаимодействия с окружающими, умение самостоятельно обслуживать себя, поддерживать порядок и создавать уют в доме, умение воспринимать и оказывать психологическую, физическую поддержку недееспособным членам семьи; сформировано сознательное репродуктивное поведение (35 \%);

2) отмечаются трудности во взаимоотношениях с окружающими, иждивенчество, несформированность волевой сферы, отсутствие целеустремленности, направленной на будущую жизнь, нет чувства ответственности, отмечается несформированность нравственного поведения в планировании семьи, отсутствие навыков повседневного правильного поведения.

Обобщая результаты диагностики по всем методам и методикам исследования, мы проанализировали данные и выделили две группы обучающихся: с низким и средним уровнем готовности к семейной жизни (с высоким уровнем обнаружено не было).

Студенты со средним уровнем готовности к семейной жизни составили $24 \%$ (6 чел.) от всех участвующих в экспериментальной работе. Это обучающиеся, которые не в полной 
мере понимают значение понятия «семья», ее функции, неправильно распределяют свой бюджет. Отмечаются несформированность нравственного поведения в планировании семьи, отсутствие навыков самосохранительного поведения.

Группа с низким уровнем готовности к семейной жизни представлена юношами и девушками - 76 \% (19 чел.). Для них создание собственной семьи не является главной ценностью в жизни, они отличаются нежеланием трудиться, не стремятся идти на конструктивное межличностное общение с окружающими. Во многом этому способствуют их личностные качества, такие как лень, отсутствие познавательной мотивации и др.

Таким образом с обучающимися, оставшимися без попечения родителей, необходимо проводить комплексную работу по формированию готовности к семейной жизни. Мы определили следующие наиболее проблемные области в создании данного личностного феномена:

- формирование установок, ценностных ориентаций на семейную жизнь;

- развитие мотивации на создание своей семьи, воспитание собственных детей;

- формирование эмоционально-позитивных представлений о семейной жизни, собственной роли в ней, будущем супруге, детях, родственниках;

- формирование практических навыков ведения домашнего хозяйства, умений заботиться и ухаживать за недееспособными членами семьи (детьми, больными, пожилыми).

Проведенное исследование продемонстрировало необходимость разработки и внедрения специальной коррекционной программы для детей-сирот и детей, оставшихся без попечения родителей [20]. Такая программа позволит сформировать у студентов, испытавших раннюю материнскую депривацию, адекватное представление о семье, ее членах и их взаимоотношениях, возникающих сложностях, а также поможет развить умения и навыки, помогающие в преодолении трудных жизненных ситуаций.

\section{Список литературы}

1. Гаранина Е. Ю. Семьеведение. М.: Флинта: МПСИ, 2013. 384 с.

2. Дементьева И. Ф. Издержки социализации детей в неблагополучной семье // Социальная педагогика: науч.практ. журнал для социальных работников и педагогов. 2015. № 2. С. 5-10.

3. Фуряева Т. В., Каблукова И. Г. Дети и подростки в трудной жизненной ситуации: педагогическая теория, практика сопровождения и интеграции. Красноярск: Изд-во КГПУ им. В. П. Астафьева, 2007. 304 с.

4. Babitskaya L. A., Bubnova I. S., Kibalnik A. V., Rerke V. I., Fedosova I. V. Theoretical and Empirical Understanding of the Concept of "Life Perspective of the Personality of Children-Orphans" // The Social Sciences. 2016. Vol. 11, is. 27. P. 6451-6458.

5. Гурова Е. В. В фокусе рубрики: Семейное жизнеустройство детей-сирот // Семейная психология и семейная терапия. 2008. № 1. С. 76-77.

6. Иванова Н. П. Деятельность образовательного учреждения для детей-сирот и детей, оставшихся без попечения родителей, по повышению успешности вхождения воспитанников в самостоятельную жизнь: метод. материал / авт.-сост. Н. П. Иванова // Академия повышения квалификации и переподготовки работников образования. 2004. № 4. С. 30-34.

7. Саракун М. Н. Сущность феномена «готовность к семейной жизни» в научной литературе // Категория «социального» в современной педагогике и психологии: материалы 4-й Всерос. науч.-практ. конф. с междунар. участием (г. Ульяновск, 2016). Ульяновск: Зебра, 2016. С. 588-593.

8. Дубровина И. В. Проблемы психологической подготовки студенческой молодежи к семейной жизни // Вопросы психологии. 1981. № 4. С. 146-151.

9. Жукова В. И. Опыт и проблемы жизнеустройства детей-сирот и детей, оставшихся без попечения родителей, в современных условиях. М.: Изд-во РГСУ, 2009. 452 с.

10. Захарова Ж. А. Социально-педагогическое сопровождение процесса воспитания приемного ребенка в замещающей семье: автореф. дис. ... д-ра пед. наук. Кострома: Костромской гос. ун-т им. Н. А. Некрасова, 2009. $45 \mathrm{c}$. 
11. Зимина Н. А. Изучение, анализ и работа по преодолению стереотипов семейной жизни у современной молодежи // Семейная психология и семейная терапия. 2011. № 2. С. 22-31.

12. Зимина Н. А. О необходимости подготовки молодежи к семейной жизни // Психологическая наука и практика: проблемы и перспективы: материалы 2-й Междунар. науч.-практ. конф. Н. Новгород, 2010. С. 216-222.

13. Ослон В. Н. Жизнеустройство детей-сирот: профессиональная замещающая семья. М.: Генезис, 2006. 368 с.

14. Прихожан А. М. Дети без семьи. М., 1990. 160 с.

15. Бобылева И. А. Индивидуальное сопровождение выпускников учреждения для детей сирот: кураторство // Социальная педагогика: науч.-практ. журнал для социальных работников и педагогов. 2013. № 1. С. 29-33.

16. Федосова И. В., Смирнова М. В. Формирование педагогической культуры у молодых родителей в условиях общеобразовательной школы // Технологии социальной работы в образовательной практике / отв. ред. А. Ю. Нагорнова. Ульяновск: Зебра, 2016. С. 88-116.

17. Воспитание будущего семьянина в условиях детского дома и школы-интерната: метод. пособие / сост. Л. М. Левина, Л. Г. Печерская, О. С. Размахова. Иркутск: Изд-во ОГОУ ЦПМСС, 2010. 120 с.

18. Дзугкоева М. Г. Психические новообразования студенческого возраста: дис. ... канд. психол. наук. М., 1997. $157 \mathrm{c}$.

19. Дохоян А. М. Исследование готовности молодежи к вступлению в брак // Семейная психология и семейная терапия. 2008. № 2. С. 38-44.

20. Федосова И. В. Модель формирования готовности к семейной жизни у студентов, оставшихся без попечения родителей // Непрерывное образование как условие устойчивого развития личности и общества: материалы междунар. науч.-практ. конф. (г. Иркутск, 4 октября 2017 г.). Иркутск: Иркут, 2017. С. 76-83.

Федосова Ирина Валерьяновна, кандидат педагогических наук, доцент, заведующая кафедрой социальной педагогики и психологии, Иркутский государственный университет (ул. Нижняя Набережная, 6, Иркутск, Россия, 664011). E-mail: Fedos-ir@yandex.ru

Кибальник Алена Вячеславовна, кандидат педагогических наук, старший преподаватель, Иркутский государственный университет (ул. Нижняя Набережная, 6, Иркутск, Россия, 664011). E-mail: kialvch@yandex.ru

Материал поступил в редакцию 20.01.2020.

DOI 10.23951/2307-6127-2020-2-220-233

\section{PREPAREDNESS TO FAMILY LIFE AMONG STUDENTS LEFT WITHOUT PARENTAL CARE: EMPIRICAL EXPERIENCE}

\section{V. Fedosova, A. V. Kibalnik}

\section{Irkutsk State University, Irkutsk, Russian Federation}

The article deals with the social and pedagogical phenomenon of preparedness to family life. The authors emphasize the leading role of family in preparing young people to the future family life and forming their responsible attitude to starting their own families. Special attention is paid to the group of students who were left without parental care and stayed at orphanages. The paper emphasizes the factors provoking distorted perception of family and incorrect understanding of social roles among this category of students. The authors present empirical data in studying preparedness to family life among university students left without parental care using the following criteria: cognitive criterion, value and motivational criterion, emotional criterion, and operational and activity criterion. Based on the diagnostics data, the authors affirm the necessity of forming preparedness to family life among this category of students on the basis of a specially developed program. The program aims at forming family values; expanding the knowledge about family, laws of its development, family etiquette, and gender psychology; promotion of successful experience of family life and education; 
interaction of education subjects in developing family and moral values and responsible attitude to being a parent.

Keywords: family, preparedness to family life, students, students left without parental care, program.

\section{References}

1. Garanina E. Y. Semyevedeniye [Family studies]. Moscow, Flinta, Moscow Psychology and Social Studies Institute Publ., 2013. 384 p. (in Russian).

2. Dementyeva I. F. Izderzhki sotsializatsii detey v neblagopoluchnoy semye [Side effects of children's socialization in disadvantaged families]. Sotsial'naya pedagogika: nauchno-prakticheskiy zhurnal dlya sotsial'nykh rabotnikov i pedagogov, 2015, no. 2, pp. 5-10 (in Russian).

3. Furyayeva T. V., Kablukova I. G. Deti i podrostki v trudnoy zhiznennoy situatsii: pedagogicheskaya teoriya, praktika soprovozhdeniya $i$ integratsii [Children and adolescents in difficult life situations: pedagogical theory, practice of support and integration]. Krasnoyarsk, Astafyev Krasnoyarsk State Pedagogical University Publ., 2007. 304 p. (in Russian).

4. Babitskaya L. A., Bubnova I. S., Kibal'nik A. V., Rerke V. I., Fedosova I. V. Theoretical and Empirical Understanding of the Concept of "Life Perspective of the Personality of Children-Orphans". The Social Sciences, 2016, vol. 11, issue 27, pp. 6451-6458.

5. Gurova E. V. V fokuse rubriki: Semeynoye zhizneustroystvo detey-sirot [In the focus of the column: Family life of orphans]. Semeynaya psikhologiya i semeynaya terapiya, 2008, no. 1, pp. 76-77 (in Russian).

6. Ivanova N.P. Deyatel'nost' obrazovatel'nogo uchrezhdeniya dlya detey-sirot i detey, ostavshikhsya bez popecheniya roditeley, po povysheniyu uspeshnosti vkhozhdeniya vospitannikov v samostoyatelnuyu zhizn: metodicheskiy material [Educational organization activity on successful integration to independent living for orphans and children left without parental care: methodological materials]. Akademiya povysheniya kvalifikatsii i perepodgotovki rabotnikov obrazovaniya, 2004, no. 4, pp. 30-34 (in Russian).

7. Sarakun M. N. Sushchnost' fenomena "gotovnost' k semeynoy zhizni" v nauchnoy literature [The main point of the phenomenon of preparedness to family life in scientific literature]. Kategoriya "sotsial'nogo" $v$ sovremennoy pedagogike i psikhologii: materialy 4-y Vserossiyskoy nauchno-prakticheskoy konferentsii s mezhdunarodnym uchastiyem (g. Ulyanovsk, 2016) [Social category in the modern pedagogy and psychology: materials of the 4th Russian National Scientific and Practical Conference with International Participation (Ulyanovsk, 2016)], Ulyanovsk, Zebra Publ., 2016. Pp. 588-593 (in Russian).

8. Dubrovina I. V. Problemy psikhologicheskoy podgotovki studencheskoy molodyozhi k semeynoy zhizni [Problems of psychological preparing of student youth to family life]. Voprosy psikhologii-Voprosy Psychologii, 1981, no. 4, pp. 146-151 (in Russian).

9. Zhukova B. I. Opyt i problemy zhizneustroystva detey-sirot i detey, ostavshikhsya bez popecheniya roditeley, $v$ sovremennykh usloviyakh [Experience and problems of settling the lives of orphans and children left without parental care in modern conditions]. Moscow, Russian State Social University Publ., 2009. 452 p. (in Russian).

10. Zakharova Z. A. Sotsial'no-pedagogicheskoye soprovozhdeniye protsessa vospitaniya priyomnogo rebenka $v$ zameshchayushchey semye. Avtoref. dis. d-ra ped. nauk [Social and pedagogic support of upbringing a child in a substitute family. Abstract of thesis of doc. of ped. sci.]. Kostroma, Nekrasov Kostroma State University Publ., 2009. 45 p. (in Russian).

11. Zimina N. A. Izucheniye, analiz i rabota po preodoleniyu stereotupov semeynoy zhizni u sovremennoy molodyozhi [Studying, analyzing and working on overcoming the stereotypes of family life among modern youth]. Semeynaya psikhologiya i semeynaya terapiyay, 2011, no. 2, pp. 22-31 (in Russian).

12. Zimina N. A. O neobkhodimosti podgotovki molodezhi k semeynoy zhizni [On the issue of necessity of preparing young people for family life]. Psikhologicheskaya nauka i praktika: problemy i perspektivy: materialy 2-oy mezhdunarodnoy nauchno-prakticheskoy konferentsii [Psychological science and practice: problems and prospects: materials of the 2nd International Scientific and Practical Conference]. Nizhny Novgorod, 2010. Pp. 216-222 (in Russian).

13. Oslon V. N. Zhizneustroystvo detey-sirot: professional'naya zameshchayushchaya semya [Settling the lives of orphans: professional substitute families]. Moscow, Genezis Publ., 2006. 368 p. (in Russian).

14. Prikhozhan A. M. Deti bez semyi [Children without families]. Moscow, 1990. 160 p. (in Russian). 
15. Bobyleva I. A. Individual'noye soprovozhdeniye vypusknikov uchrezhdeniya dlya detey-sirot: kuratorstvo [Individual support of orphanage graduates: tutorship]. Sotsial'naya pedagogika: nauchno-prakticheskiy zhurnal dlya sotsialnykh rabotnikov i pedagogov - Social pedagogy: scientific and practical journal for social workers and teachers, 2013, no. 1, pp. 29-33 (in Russian).

16. Fedosova I. V., Smirnova M. V. Formirovaniye pedagogicheskoy kul'tury u molodykh roditeley v usloviyakh obshcheobrazovatel'noy shkoly [Forming of pedagogical culture among young parents at schools]. Tekhnologii sotsial'noy raboty v obrazovatel'noy praktike. Otv. red. A. Yu. Nagornova [Technologies of social work in educational practice. Ed. A. Yu. Nagornova]. Ulyanovsk, Zebra Publ., 2016, pp. 88-116 (in Russian).

17. Vospitaniye budushchego semyanina $v$ usloviyakh detskogo doma i shkoly-internata: Metodicheskoye posobiye [Educating a future dfamily man at orphanages and boarding schools: workbook]. Irkutsk, Center of Psychological, Medical and Social Support Publ., 2010. 120 p. (in Russian).

18. Dzugkoyeva M. G. Psikhologicheskiye novoobrazovaniya studencheskogo vozrasta. Dis. kand. psikhol. nauk [New psychological formations of student age. Dis. cand. of psychol. sci.]. Moscow, 1997. 157 p. (in Russian).

19. Dokhoyan A. M. Issledovaniye gotovnosti molodezhi k vstupleniyu v brak [Research on young people's preparedness for marriage]. Semeynaya psikhologiya i semeynaya terapiya, 2008, no. 2, pp. 38-44 (in Russian).

20. Fedosova I. V. Model' formirovaniya gotovnosti k semeynoy zhizni u studentov, ostavshikhsya bez popecheniya roditeley [Model of forming preparedness for family life among student left without parental care]. Nepreryvnoye obrazovaniye kak usloviye ustoychivogo razvitiya lichnosti i obshchestva: materialy mezhdunarodnoy nauchnoprakticheskoy konferentsii (g. Irkutsk, 4 oktyabrya 2017 g.) [Continuing education as a condition for sustainable development of personality and society: materials of international scientific and practical conference (Irkutsk, October 4th, 2017)]. Irkutsk, Irkut Publ., 2017. Pp. 76-83 (in Russian).

Fedosova I. V., Irkutsk State University (ul. Nizhnyaya Naberezhnaya, 6, Irkutsk, Russian Federation, 664011). E-mail: Fedos-ir@yandex.ru

Kibalnik A. V., Irkutsk State University (ul. Nizhnyaya Naberezhnaya, 6, Irkutsk, Russian Federation, 664011).E-mail: kialvch@yandex.ru 